


\title{
Contradições na "Cidade do charme": a interseccionalidade nas desigualdades em Baltimore, Estados Unidos
}

\author{
The contradictions of the "Charm city": the \\ interseccional inequalities of Baltimore, USA
}

\author{
Camila Daniel* \\ http://dx.doi.org/10.51861/ded.dmvu.1.015 \\ Recebido em 9 de fevereiro de 2021. Aceito em 30 de março de 2021.
}

\begin{abstract}
Resumo
Este artigo analisa a interseção entre raça, classe e fluxos migratórios no espaço urbano, enfocando no caso de Baltimore, EUA. Cidade majoritariamente negra, Baltimore enfrenta uma segregação racial histórica, agravada pelos ciclos de crise do capitalismo. No final do século XX, a cidade sofreu com a desindustrialização, o desemprego estrutural, uma brusca queda populacional e uma política de austeridade. Na tentativa de recuperar a economia da cidade, Baltimore mergulhou numa reforma urbana que privilegia os bairros majoritariamente brancos, através de empreendimentos corporativos e do investimento em equipamentos de hospedagem, lazer, esporte, turismo e infra-estrutura que deram a Baltimore a alcunha de "cidade do charme". Enquanto isso, os bairros negros sofrem ou com o desinvestimento ou com a gentrificação. Baseando-me numa análise bibliográfica e no trabalho de campo etnográfico realizado entre 2016 e 2019 , concluo que a imigração complexifica as tensões raciais e as desigualdades no espaço urbano.
\end{abstract}

Palavras-chave: Cidade; Racismo; Pobreza; Imigração; Latinos.

\begin{abstract}
This article analyzes the intersection between race, class, and migratory flows in the urban space, focusing on the case of Baltimore, USA. A city of a majority Black population, Baltimore faces historic racial segregation, aggravated by several crisis cycles. At the end of the twentieth century, the city suffered from deindustrialization, structural unemployment, a sharp population drop, and austerity policies. In an attempt to recover the city's economy, Baltimore plunged into an urban reform that favors mostly white neighborhoods, through corporate ventures and investment in accommodation, leisure, sports, tourism, and infrastructure equipment that gave Baltimore the nickname of "Charm City". Meanwhile, Black neighborhoods undergo either divestment or gentrification. Based on a bibliographic analysis and ethnographic fieldwork carried out between 2016 and 2019, I conclude that immigration complexifies racial tensions and inequalities in the urban space.
\end{abstract}

Keywords: City; Racism; Poverty; Immigration; Latins.

\footnotetext{
* Doutora em Ciências Sociais (PUC-Rio); Professora adjunta do Departamento de Ciências Administrativas e Sociais (DCAS) da Universidade Federal Rural do Rio de Janeiro. Professora visitante do Institute of Latin American Studies da Columbia University. https://orcid.org/0000-0003-1199-2028. E-mail: camiladaniel@gmail.com
} 


\section{INTRODUÇÃO}

No dia 6 de janeiro de 2021, o mundo se chocou com uma cena: a invasão da sede do congresso dos EUA por um grupo de militantes majoritariamente brancos e brancas de extrema direita que protestavam contra a derrota de Donald Trump nas urnas. Em maio de 2020, o mundo testemunhou o brutal assassinato de George Floyd por um policial branco em Minneapolis. Estes dois casos colocaram na ordem do dia um debate profundo, antigo e crucial para os Estados Unidos e o mundo: o papel do racismo hoje. Muitos acreditavam que os dois governos Obama eram um sinal de que os Estados Unidos tinham finalmente se tornado um país "pós-racial”, ou seja, um país hegemonicamente interracial onde o racismo já não importaria. Eles acordaram do sonho quando, em 2016, Donald Trump venceu as eleiçốes com uma agenda abertamente racista.

No ano da vitória de Trump, eu estava em um pós-doutorado em Baltimore, cidade majoritariamente negra, ao norte da capital Washington. Marcada historicamente por profundas desigualdades sociais combinadas com o racismo estrutural, Baltimore é caracterizada pela segregação da cidade em espaços negros e espaços brancos. Em 2015, ela ganhou o protagonismo nos noticiários quando se uniu ao movimento \#BlackLivesMatters depois que o jovem negro Freddie Gray foi assassinado pela polícia.

A divulgação do resultado parcial das eleiçôes de 2016 aconteceu em novembro, mês da consciência negra no Brasil e do meu aniversário. Eu estava em Boston participando de uma conferência na universidade de Harvard, hospedada numa casa pelo Airbnb. A dona da casa, uma mulher branca, ficou desolada. O seu olhar vago revelava sua surpresa e incredulidade com a vitória de Trump. "Acho que vou me mudar para o Canadá", desabafou. Ela falava comigo, mas, principalmente com ela mesma.

Obviamente, a possibilidade de mudar de país por causa do então novo presidente era um privilégio que muitas pessoas que vivem nos Estados Unidos não tinham. Por outro lado, a surpresa com a vitória de Trump também indicava que sua plataforma correspondia às demandas de muitas pessoas do país, o que, por sua vez, apontava o racismo como ainda estruturante da sociedade estadunidense. Apesar da segregação racial não ser mais permitida por lei, a desigualdade racial continua uma realidade nos Estados Unidos. Um exemplo disso é que, em 2011, os afro-estadunidenses possuíam uma riqueza líquida de apenas $\$ 200$, os latinos $\$ 350$, os asiáticos $\$ 1950$ e os brancos $\$ 2300$ (IRANI et al., 2018).

De volta a Baltimore, me encontrei com meus amigos - a maioria engajada em movimentos sociais anti-racistas e/ou anti-capitalistas. Eles também estavam desolados. Mesmo assim, fizeram a leitura que a eleição de Trump 
era o sintoma de problemas muito antigos ao mesmo tempo atuais: a desigualdade social, a segregação racial e a interseção deles com outras estruturas de poder, como a discriminação de grupos étnicos e a exploração dos processos migratórios. Ocupando as primeiras posiçóes no ranking de cidades mais pobres e violentas dos Estados Unidos, Baltimore tem na sua população pobre uma maioria negra. De acordo com o censo de 2010, a renda familiar anual em Baltimore era de $\$ 62751$ na população branca, $\$ 50531$ na asiática, \$44116 na latina e \$33801 na população negra (CFED, 2017).

Este artigo tem o objetivo de analisar as desigualdades em Baltimore, também conhecida como "cidade do charme" numa perspectiva interseccional (COLLINS, 2016; 2019). Dou enfoque à articulação entre raça, classe e fluxos migratórios. No debate sobre os fluxos migratórios, discutirei em que medida a imigração de europeus brancos de inícios do século XX e de imigrantes latinos no século XXI complexifica a tensão racial, a segregação e as desigualdades sociais no espaço da cidade. A partir do meu lugar como mulher, negra, brasileira e intelectual, coloco em debate a importância do conceito de interseccionalidade como ferramenta para analisar como os sistemas de opressóes se articulam, agravando as desigualdades no espaço urbano. Este artigo se baseia na análise bibliográfica e no trabalho de campo etnográfico realizado entre 2016 e 2019. Os imigrantes - e seus descendentes - têm participado das transformaçóes urbanas em Baltimore, muitas vezes compactuando com o privilégio branco e reforçando o racismo anti-negro. Enquanto os imigrantes brancos europeus nas primeiras décadas do século $\mathrm{XX}$ encontraram no privilégio branco um auxílio para se estabelecerem na cidade, os imigrantes latinos - de muitas identidades raciais e étnicas - hoje ocupam um lugar dúbio entre a Baltimore branca e a Baltimore negra, as políticas neoliberais, a xenofobia e o racismo anti-negro, vivendo uma experiência particular de racialização.

\section{INTERSECCIONALIDADE: REPENSANDO AS DESIGUALDADES}

A atual polarização política estadunidense tem na raça um de seus elementos centrais. Ela demonstra que a raça não é algo excepcional, mas sim fundante da sociedade dos Estados Unidos.

Entendo a raça não como fenômeno biológico, mas uma construção social que hierarquiza os indivíduos entre humanos (brancos e brancas) e não-humanos (FANON, 2008), as pessoas racializadas. A raça estabelece assim uma linha divisória. Aqueles classificados fora da linha do "humano" têm sua existência caracterizada pela cotidiana violência física e simbólica. Tal violência se manifesta de múltiplas formas: na dimensão estrutural - 
como o acesso ao emprego, educação, moradia e as demais desigualdades materiais -, e na dimensão interpessoal - na discriminação nas interações face a face (OMI, WINANT, 1994; TELLES, 2004). A noção de raça fundamenta o racismo, sistema global que operacionaliza a desumanização das vidas não-brancas desde a invasão colonial europeia às Américas no século XVI (QUIJANO, 2000).

Enquanto desumaniza as vidas não-brancas, o racismo garante privilégios para pessoas brancas. Esses privilégios e desvantagens assumem formas diferentes de acordo com o contexto histórico como cada sociedade viveu a dominação colonial. Analisando as Américas, Quijano (2000) discute que tal dominação continua a vigorar mesmo depois que o colonialismo foi derrocado e os países das Américas conquistaram a independência. A reprodução da dominação colonial apesar do fim do colonialismo se dá a partir da reprodução de desigualdades entre os brancos descendentes dos colonizadores europeus - considerados superiores - e as populaçóes racializadas. Tal ideologia deixa suas sequelas ainda hoje. No caso da América da Latina, por exemplo, Gonzalez (1988) observou que a construção das culturas nacionais, baseadas na ideologia da mestiçagem, escamoteava o projeto de branqueamento que desvalorizava a participação negra e indígena na construção do continente.

No contexto neoliberal, a colonialidade é renovada cotidianamente por exemplo no crescimento do complexo industrial de prisôes que atinge desproporcional populações negras e imigrantes. Ela também se manifesta no enxugamento de políticas sociais para os mais vulneráveis e o investimento público em negócios privados. Intersubjetivamente, a colonialidade é reproduzida nos vários mecanismos de apagamento das subjetividades não-brancas por meio, por exemplo, do epistemicídio e da reprodução da branquitude como padrão de beleza, inteligência, respeito e, em última instância, de humanidade.

Tal noção de humanidade, fundamental para as instituições modernas, tem entre suas raízes uma ideia de cidadania baseada nas revoluçóes burguesas - entre elas a revolução americana e a revolução francesa. Discutindo a importância de descolonizar as noçóes de direito, cidadania e democracia, Pires (2019) ressalta que o Estado moderno, ao definir as revoluçóes burguesas como sua base histórica e política, fez um pacto com a branquitude. Assim, ele atualiza na república a desumanização das populaçóes negras e indígenas do período colonial. Além disso, a construção do Estado moderno jogou para o esquecimento a relevância da revolução haitiana.

Ocorrida no mesmo período histórico que as revoluçóes americana e francesa, a revolução haitiana foi a primeira revolução negra nas Américas. 
Ela foi a única revolução que conquistou concomitantemente o fim da escravidão e a independência. Todos os outros movimentos pela independência no continente americano foram liderados pelas elites descendentes de europeus. Apressadas em declarar o fim da independência, elas tardaram em declarar o fim da escravização.

A escravização tinha como justificativa a ideia de que os africanos não tinham alma. Por isso, poderiam ser reduzidos à propriedade dos senhores. A propriedade, por sua vez, é um dos direitos fundamentais garantidos pelas constituiçóes burguesas. Isto significa que os recém-formados Estados nasceram renovando a desumanização das populações negras, legitimando juridicamente a exploração de suas vidas. Enquanto os senhores brancos tinham o direito a propriedade, os sujeitos negros eram as propriedades possuídas pelos senhores brancos. O Estado haitiano independente foi o único que nasceu reconhecendo os negros como cidadãos e, mais que isso, como humanos e não como propriedades. O apagamento da revolução haitiana da história do Estado moderno e a valorização das revoluções burguesas como alicerces da democracia liberal comprovam o compromisso do Estado com a manutenção das estruturas coloniais (PIRES, 2019, p. 72).

Realizando uma releitura do conceito de amefricanidade de Lélia Gonzalez, Pires propóe uma transformação dos significados de Estado e democracia a partir da experiência de organização política das mulheres negras e populações periféricas. Apesar de muitas vezes se dizerem desinteressados por política, as populações periféricas desenvolvem práticas e análises que desafiam os papéis de subalternidade impostos a elas. Porém, o vocabulário sobre a política é colonizado pelos sentidos hegemônicos da democracia liberal - associada à política institucional e à sociedade civil burguesa branca. Isso afeta negativamente a auto-percepção das pessoas periféricas como sujeitos políticos. Assim, a autora propôe a elaboração de uma nova gramática de direitos fundamentada nos saberes de mulheres negras e indígenas, uma perspectiva amefricana (PIRES, 2019, p.73).

A reflexão de Pires dialoga com o debate sobre a "epistemologia feminista negra” realizado por Collins (2019). Para Collins, as mulheres negras ao longo da história elaboraram estratégias para garantir sua subsistência e a de suas famílias, organizar suas comunidades e exigir melhores condições de vida. Muitas dessas estratégias assumem formas e conteúdos muito diferentes das maneiras de participação política reconhecidas pelas ciências sociais. Como consequência, as mulheres negras, principalmente as pobres, geralmente têm suas açôes políticas invisibilizadas. Analisando as trabalhadoras domésticas negras, por exemplo, Collins (2016) analisa o lugar estratégico que elas ocupavam na compreensão da realidade estadunidense. $\mathrm{O}$ trabalho 
delas, embora associado à dominação de raça, gênero e classe, lhes permitiam ter acesso à intimidade das famílias brancas (COLLINS, 2016), já que eram "quase da família” (DIAS, 2019). A partir desse lugar, elas observavam que grande parte do êxito que os brancos tinham não se devia tanto às suas qualidades extraordinárias, mas aos privilégios que o racismo lhes garantia.

Embora neste artigo eu não enfoque nas mulheres negras, o conceito de interseccionalidade nos possibilita compreender como diferentes camadas de poder se coadunam na realidade, complexificando o espaço urbano. A interseccionalidade não é um conceito fechado. O surgimento do termo remonta do movimento de mulheres racializadas estadunidenses de finais dos anos 70 (COMBAHEE RIVER COLLECTIVE, [1977] 2015), mas mulheres racializadas de outras localidades aplicavam a noção de interseccionalidade mesmo não empregando essa palavra (BILGE \& COLLINS, 2016, p. 3), por exemplo, feministas negras brasileiras como Lélia Gonzalez. Além disso, a interseccionalidade associada ao debate sobre a colonialidade nos abre um caminho para fugir da falsa dicotomia entre políticas de redistribuição e políticas de reconhecimento (FRASER, 2006).

Ganhando visibilidade nas últimas décadas do século XX, as demandas por reconhecimento muitas vezes são cooptadas por políticas identitárias que ignoram a dimensão material do poder e reproduzem uma fragmentação política conveniente para o aprofundamento das desigualdades no capitalismo neoliberal. Por outro lado, a ideia de que a classe seria suficiente como categoria analítica e instrumento de mobilização política muitas vezes fez vistas grossas à exploração que o capitalismo faz de outros sistemas de opressões, como raça, gênero, a sexualidade, status migratório, nacionalidade, etnicidade e como eles se manifestam no espaço urbano. Enquanto Marx pensava em formas de organizar a classe trabalhadora inglesa no século XIX, do outro lado do oceano Atlântico as populaçốes escravizadas lutavam por sua humanidade.

Neste artigo, o conceito de interseccionalidade será nossa ferramenta para analisar as transformações em Baltimore, dando enfoque para a interseção entre classe, raça e etnicidade, considerando, nesta última, a relevância dos fluxos migratórios para uma compreensão interseccional das contradições de Baltimore no contexto neoliberal. Apesar do gênero ser uma das camadas de poder centrais para a compreensão da realidade, como indica o conceito de interseccionalidade, os dados etnográficos e a bibliografia pesquisada não me oferecem recursos para incluí-lo de maneira mais profunda neste trabalho. No entanto, o gênero tangencia esta análise, já que eu sou uma mulher negra, questão central principalmente nos dados etnográficos. 


\section{OS CAMINHOS QUE ME LEVARAM À BALTIMORE}

Localizada a 56 quilômetros de Washington D.C, capital dos Estados Unidos, Baltimore é considerada uma transição entre o sul e o norte (McDOUGALL, 1993). Esta representação está associada a alguns fatos que ultrapassam sua localização geográfica. Entre eles está como o racismo se manifesta na cidade. O sul dos Estados Unidos é reconhecido pela histórica defesa à escravização no suprimento da demanda por mão de obra agrícola. No pós-guerra civil, que culminou com o fim da escravidão, muitos estados do sul fomentaram uma política de segregação racial que culminou com a aprovação dos código Jim Crow. No norte do país não vigorou uma política oficial de segregação racial. Isso não significa que o racismo não era relevante na vida social do norte, mas que ele assumiu formas extra-oficiais. Além disso, o desenvolvimento industrial do início do século XX de cidades do norte como Nova Iorque, Chicago e Filadélfia, atraiu migrantes de muitas partes dos Estados Unidos e do mundo, o que complexificou o espaço urbano, com a formação, por exemplo, de enclaves étnicos (CARD, 2009).

Já nos primeiros anos do século XX, Baltimore vivenciou um crescimento industrial que atraiu imigrantes europeus. Eles deixaram seu legado no espaço urbano em bairros ainda hoje existentes como a Little Italy (Pequena Itália) e a Greektown (Cidade Grega). Em sua história, Baltimore também abrigou uma população negra nativa e migrante que sofreu com as políticas de segregação racial. Tais políticas restringiu seu acesso à moradia, transporte, educação e saúde. Concomitantemente, Baltimore também foi palco da ação coletiva de ativistas negros e negras, incluindo, por exemplo o movimento abolicionista no século XIX, diferentes organizaçóes no movimento pelos direitos civis na década de 1960 e o movimento \#Blacklivesmatter desde 2015. A segregação racial em Baltimore ganhou novos contornos principalmente com as transformaçốes políticas e econômicas das últimas décadas do século XX, o que discutiremos adiante. Desde então, Baltimore sofreu com a progressiva perda de empregos e com a saída de muitos moradores, o que a tornou uma cidade majoritariamente negra. De acordo com o censo de 2010, 62,4\% da população de Baltimore é negra; 30,5\% branca; 5,3\% hispânico/latino; 2,6\% asiática e 0,3\% índio americano/nativo do Alaska. Baltimore também é afetada por altos índices de pobreza, com $21,2 \%$ da população vivendo abaixo da linha da pobreza (US CENSUS BUREAU, 2019)

Minha relação com Baltimore começou em 2016, quando realizei um pós-doutorado, na Morgan State University. Minha felicidade de ir para Baltimore se contrastava com as notícias que eu lia e com a opinião de meus amigos que moram nos Estados Unidos. Em 2015, Baltimore tinha vivido uma série de manifestações após o assassinato de Freddie Gray. Abundava 
nos noticiários matérias sobre a violência policial na cidade e os problemas raciais na cidade, além das elevadas taxas de homicídio e tráfico de drogas. Quando eu disse para um amigo estadunidense branco morador de Nova Iorque que ia morar em Baltimore, ele ficou chocado. Ele passou meses tentando me convencer a mudar o destino: Baltimore era um lugar para eu evitar. Outra amiga, latina negra que cresceu no norte da Virgínia, não muito distante de Baltimore, confirmou o alerta do meu amigo branco. Ela disse que Baltimore era horrível. Quando ela era criança e se comportava mal, seu pai dizia que iria largá-la no oeste de Baltimore, mesma área onde morava Freddie Gray. Como um ex-morador de Baltimore, David Harvey (2015, p.181) descreve a cidade como uma confusão: "Não o tipo de confusão atraente que faz das cidades fascinantes lugares a serem explorados, mas uma terrível confusão". A aveludada voz de Nina Simone colocou a decadência de Baltimore em canção na música de mesmo nome. Alguns versos da música ecoam: "bêbados na rua, dormindo na chuva ..., a cidade está morrendo".

Cheguei em Baltimore no gélido inverno de 2015/2016, mais precisamente em dezembro, algumas semanas antes de começar o pós-doutorado. Eu precisava encontrar um lugar para morar. Assim que cheguei, me hospedei próxima da estação de trem e da Universidade de Baltimore para iniciar essa procura. Visitei alguns apartamentos na área central da cidade. Como eu não dirigia e sabia que precisaria me deslocar para fazer meu trabalho de campo, minha prioridade era morar numa vizinhança com acesso a transporte público. As pesquisas que realizei indicavam que o melhor lugar seria perto do Inner Harbor. O Inner Harbor era o porto que contribuiu para o apogeu de Baltimore na era da industrialização, já que ele escoava parte da produção. Nos anos 80 , ele passou por um processo de revitalização que o transformou no principal ponto turístico da cidade. Ocupado por restaurantes, lojas, hotéis e outros equipamentos turísticos (Figura 1), o Inner Harbor sela o pacto da cidade com o redesenvolvimento através do setor de serviços e do turismo (HARVEY, 2015; RIZZO, 2019).

O primeiro apartamento que me interessou ficava num condomínio de prédios na rua North Howard. O prédio exalava imponência. Sua luxuosa arquitetura me conquistou. Meu fascínio foi ainda maior quando soube o valor do aluguel. Eu pagaria num apartamento de um quarto num prédio luxuosamente reformado na área central de Baltimore o mesmo valor ou talvez menos do que pagaria num quarto de porão em Washington D.C bem longe do centro. Eu pensei em morar lá já que muitos dos interlocutores da minha pesquisa moravam nas proximidades da capital. Infelizmente, minha bolsa não era suficiente para pagar um aluguel lá. 


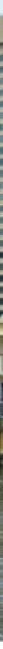

Fonte: Arquivo pessoal, 2016.

Além do preço acessível e do luxo do prédio, fiquei muito animada pois o corretor me garantiu alugar o apartamento sem burocracias. Praticamente, ele só precisaria do meu nome completo. Fiquei muitíssimo empolgada, mas decidi pensar. Mesmo no meio da emoção, observei algo estranho do lado de fora do prédio. Sua grandiosa imponência contrastava com as ruas no entorno: elas tinham um "quê" de abandono e decadência. Mesmo sem ainda conhecer o espaço urbano e a história de Baltimore, achei estranho que perto do prédio havia tantas lojas fechadas. As poucas pessoas que passaram por mim usavam roupas gastas e tinham no semblante uma melancolia revoltada. Próximo do prédio, havia uma estação do Light Rail, o VLT de Baltimore. Isso me animou, já que transporte público era um dos meus requisitos. Mas a sensação negativa que eu tive naquela visita - que aconteceu à luz do dia -, me fez imaginar como seria eu, uma mulher negra, circular sozinha por aquelas ruas de noite (Figura 2). Um fato que também me intrigou foi que o corretor me ligou muitas vezes após a visita. Fiquei desconfiada. Eu entendia que ele tinha interesse que eu fechasse o negócio logo. Porém, suas insistentes ligaçóes indicavam um desespero que nenhum outro corretor havia demonstrando. Me senti pressionada, o que me fez analisar com mais calma a ideia de me mudar para lá.

Desisti do apartamento da rua North Howard. Escolhi morar noutro prédio da mesma administradora, a Southern Management, na rua North Charles. Poucas semanas depois de me estabelecer em Baltimore, me dei 
conta que realmente tinha feito uma boa escolha. A North Howard ocupa uma área importante da cidade que tem passado por um processo de revitalização. Porém, muitas quadras da rua têm lojas abandonadas, pouca iluminação e poucos transeuntes, o que produz em mim uma sensação de perigo. Eu também aprendi que, como mulher e pedestre, eu deveria planejar muito bem meu caminho antes de sair de casa. Ao cruzar uma esquina desconhecida, eu poderia me deparar com ruas e becos escuros e com o recorrente assédio masculino, principalmente à noite.

Figura 2: Rua North Howard. Placa de "Now Leasing" (Aluga-se) no prédio onde cogitei morar (lado esquerdo)

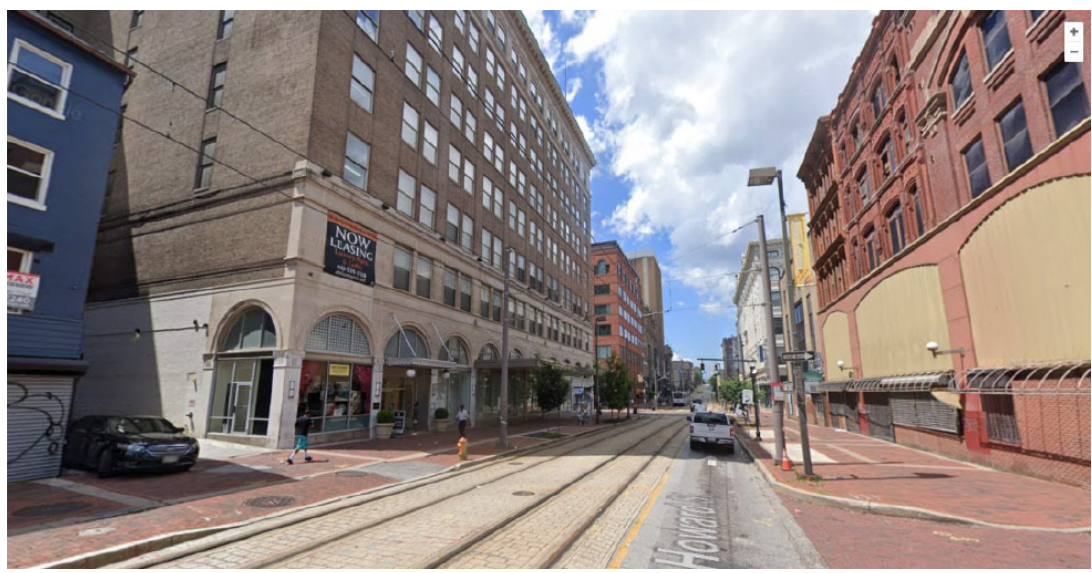

Fonte: Street View, Google Maps. Acesso em 22 Fev. 2021.

Um caso assim aconteceu comigo quando, no meu primeiro mês na cidade, fui a uma aula de dança afro no Eubie Blake Cultural Center, na rua North Howard. Como o local ficava perto da minha casa, quis economizar. Ao invés de pegar um uber, voltei andando para casa. Para evitar me perder na cidade de noite, segui direto a North Howard até chegar perto da área onde morava. No caminho, avistei um grupo de cerca de 5 jovens, parados, no frio e no escuro. Eu não sabia o que eles estavam fazendo. Fiquei com medo. Quanto mais eu me aproximava deles, o temor aumentava. Percebendo minha aproximação, eles concentraram a atenção em mim, falando alto na minha direção. Eu não entendi o que eles disseram - tenho muita dificuldade de entender o sotaque de Baltimore. Mas pelo tom e pela linguagem corporal dos jovens, entendi que eram cantadas. Os jovens estavam fazendo o "Loitering”, termo que eu não conhecia. Numa tradução literal, "loitering” significaria "vadiagem". Em Baltimore, o termo é usado para se referir ao grupo 
de pessoas, quase sempre homens afro-estadunidenses que ficam parados na entrada de prédios, bares e lojas interagindo entre si sem um motivo óbvio, às vezes conversando, eventualmente assediando transeuntes ou pedindo dinheiro. $\mathrm{Na}$ área onde eu residia, muitos estabelecimentos exibiam placas de "No loitering", alertando para a criminalização dessa prática.

Disfarçando o pavor, apertei o passo para chegar em casa o quanto antes. Já em casa, aliviada, agradeci aos céus por ter desistido de morar na North Howard. Apesar de localizada a poucos quarteiróes do Inner Harbor, do Centro de Convençóes e do estádio de beisebol, áreas que protagonizam a revitalização de Baltimore, a rua North Howard ainda carrega as marcas históricas das transformações econômicas, demográficas e de política urbana que provocaram o esvaziamento do centro da cidade.

A North Charles é uma das ruas que corta Baltimore de norte a sul, assim como a North Howard. A divisão entre as partes norte e sul da cidade fica nas proximidades do Inner Harbor. Eu morava há aproximadamente 4 quadras do Inner Harbor. Além do Inner Harbor, outros pontos importantes da cidade traçam a rua North Charles, como a estação de trem, o Walters Museum e um dos campi da Universidade Johns Hopkins, maior empregadora da cidade, também um dos maiores investidores na transformação do espaço urbano. A rua North Charles também era a rota principal de 2 linhas de ônibus convencionais. Uma delas me deixava muito perto da Morgan State University, universidade com a qual eu realizava meu pós-doutorado. Além disso, a rua também é rota da linha roxa do Charm City Circulator, linha de ônibus gratuito que interliga determinadas partes da cidade. A uma quadra de onde eu morava havia ainda uma estação de metrô e um ponto onde paravam ônibus para as mais diferentes partes da cidade, incluindo a região leste, onde se concentra a população latina, importante para meu trabalho de campo. E na rua imediatamente paralela a ela, a rua Cathedral, foi instalada a ciclovia de Baltimore. O prédio onde eu decidi morar fazia parte de um complexo de construçóes chamado Charles Plaza. Na entrada do complexo, havia um supermercado, do lado direito e uma praça de alimentação, do lado esquerdo (Figura 3). 
Figura 3: Complexo Charles Plaza. No centro, o prédio onde morei. Do lado inferior direito está supermercado Street Market e do inferior esquerdo a praça de alimentação

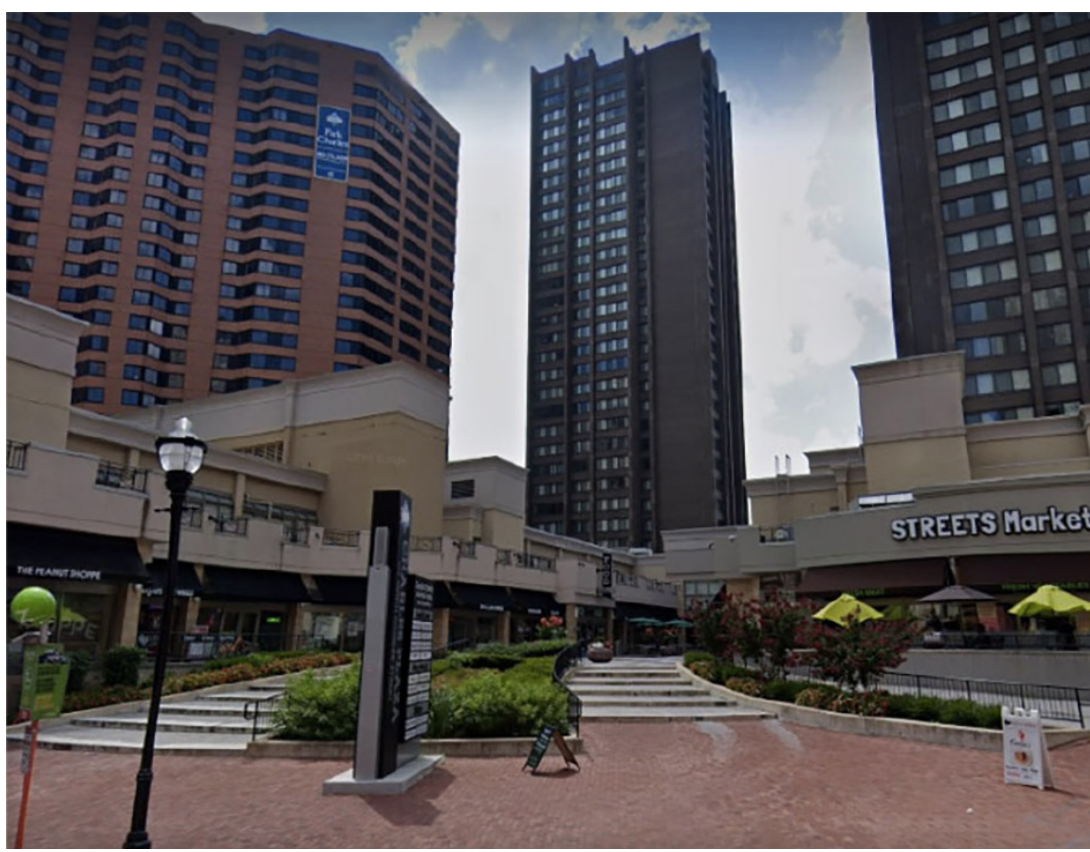

Fonte: https://www.facebook.com/CharlesPlazaFoodCourt/photos/a.11

\section{BALTIMORE, A CIDADE DO CHARME?}

O zoneamento (zoning) é um mecanismo de planejamento urbano por meio do qual os municípios regulamentam o uso da terra e o valor das propriedades. Na virada do século XIX para o XX, os governos municipais tinham no zoneamento um instrumento para regular o crescimento das cidades diante do incremento do número de migrantes internos e estrangeiros, a escassez de moradia, a falta de saneamento e a proliferação de doenças, principalmente nos bairros pobres.Baltimore foi a primeira cidade a aprovar um decreto de zoneamento que legitimou juridicamente a segregação racial em 1910 (McDOUGALL, 1993; POWER, 1983; SILVER, 1997). O decreto proibiu pessoas negras de residir em áreas onde mais de $50 \%$ da população fosse branca e vice-versa, sob o risco de pena de multa ou prisão de 30 dias a um ano. Segundo o documento, seu objetivo era "preservar a paz, prevenir o conflito (...) entre as raças brancas e "de cor" na cidade de Baltimore e promover o bem-estar geral na cidade, provendo, sempre que aplicável, o uso de 
quarteirões separados para brancos e "pessoas de cor” para residência, igrejas e escolas” (apud POWER, 1983, p. 299- 303).

O decreto foi resultado da mobilização que moradores brancos da região de Eutaw Place fizeram depois que o advogado negro George W. F McMechen e sua família se mudaram para lá. Enquanto McMechen encontrou no bairro majoritariamente branco uma oportunidade para acessar uma moradia digna que sua condição de classe lhe permitia - já que os bairros negros sofriam com a falta de investimento -, os moradores brancos encararam a chegada de McMechen como uma ameaça que abriria o bairro para outras famílias negras, o que levaria à degradação e à proliferação de doenças. Indignados, os novos vizinhos de McMechen receberam ele e sua família com demonstraçóes de violência física e encaminharam uma petição à prefeitura exigindo providências. Em dezembro de 1910, o decreto de zoneamento de Baltimore foi aprovado. McMechen ousou cruzar a "linha de cor” que impedia a população negra usufruir das áreas da cidade mais infraestrutura, mesmo quando tinham os recursos materiais para isso (SILVER, 1997; POWER, 1983). Assim, a população negra, mesmo quando pertencente à classe média, continuava alijada na zona do não-ser (FANON, 2008).

O primeiro decreto de zoneamento de Baltimore provocou um agravamento das condiçóes de vida das populaçóes negras. Limitadas a morar em bairros majoritariamente negros, a crescente população negra demandava mais casas, porém novas casas não eram construídas em seus bairros. Como consequência, o aumento da demanda negra por moradia provocou um aumento dos preços dos imóveis nos bairros negros. Por outro lado, as novas moradias na cidade eram construídas em áreas brancas, financiadas por grupos étnicos e sindicatos que se recusavam a dar crédito a negros. Os negros da classe média eram impedidos de comprar imóveis nas residências novas, já que elas eram construídas nos bairros majoritariamente brancos (SILVER, 1997; POWER, 1983). As famílias negras da classe média com condições de comprar uma casa tinham nos imóveis na Druid Hill Avenue, oeste da cidade, a principal oferta. A avenida demarcava a oeste o limite da cidade disponível para eles (POWER, 1983, p. 298).

$\mathrm{O}$ decreto de Baltimore inspirou a aprovação de decretos similares em outras cidades do sul do país. Em 1917, a Suprema Corte declarou o zoneamento racial inconstitucional. A eliminação do decreto de zoneamento racial do sistema jurídico de Baltimore não aniquilou a segregação racial. Diferentes mecanismos extra-jurídicos foram criados para, de um lado, desalojar os bairros negros empobrecidos das áreas centrais da cidade e do outro, evitar que os negros habitassem os bairros majoritariamente brancos 
(BROWN, 2021). Empresas dos ramos bancário e imobiliário tiveram um papel importante neste processo. O setor bancário contribuiu ativamente para a segregação racial em Baltimore facilitando o acesso a crédito às famílias brancas, enquanto dificultava o crédito a famílias negras, inclusive cobrando juros mais altos para elas. Além disso, o setor de investimento contribuiu para a segregação racial do espaço urbano de Baltimore incentivando o que foi apelidado de "Redlining" (alinhamento vermelho). O "Redlining" era um modelo de planejamento que marcava de vermelho no mapa as áreas consideradas arriscadas para receber investimentos públicos e privados. Os riscos eram calculados considerando a qualidade dos imóveis disponíveis, a inserção da população local no mercado de trabalho e a raça dos moradores (McDOUGALL, 1993).

Desde a década de 70, Baltimore tem sofrido com as transformaçóes econômicas e políticas do contexto neoliberal, entre elas a desindustrialização e as políticas de austeridade. Tal realidade transformou a cidade do apogeu com as atividades da indústria e do porto nos períodos de guerra para uma continuada decadência caracterizada pela: perda de postos de trabalho na manufatura; aumento do trabalho precário no crescente setor de serviços; a vertiginosa queda populacional; aumento da população nos subúrbios como áreas de expansão do capital imobiliário e uma política de austeridade que combinou o enxugamento do investimento público em políticas sociais com uma política fiscal dura com os moradores que permaneceram na cidade, mas leve para as grandes corporações (HARVEY, 2015). Os empregos industriais migraram para o sul do país e para o exterior, fazendo Baltimore perder um total de 250 mil vagas de emprego nos setores industriais e portuários (HARVEY, 2015, p. 192). Os novos empregos eram mais precários, concentrando em áreas como limpeza, portaria, estacionamento e segurança. As transformações no mercado de trabalho alteraram também o perfil da força de trabalho. De majoritariamente masculina nos anos de prosperidade da indústria, ela se tornou cada vez mais negra e feminina. Foi neste contexto que a população de Baltimore se transformou em majoritariamente negra.

Por outro lado, o governo municipal estabeleceu parcerias públicoprivadas com o objetivo de revitalizar o Inner Harbor e o centro da cidade. O complexo de prédios Charles Plaza faz parte do primeiro empreendimento de renovação urbana de Baltimore, iniciado em 1959. Empresários locais viram no projeto de renovação urbana uma oportunidade de tornar Baltimore mais competitiva na disputa por turismo e negócios. O complexo inclui um edifício de escritórios, outro de moradias, além de área de estacionamento e uma praça, que serviria como área de lazer. O projeto inovou ao estabelecer a parceria público-privada como forma de gestão urbana, que, anos mais tarde, 
se tornou o padrão dos outros projetos de renovação urbana de Baltimore (RIZZO, 2019, p. 261). Além dos projetos de renovação, a prefeitura de Baltimore investiu também em propaganda. Tentando transformar a reputação de Baltimore, o governo local elaborou campanhas de marketing para difundir uma imagem da cidade para atrair turistas, visitantes, conferencistas e empresários para os novos empreendimentos (RIZZO, 2019). O slogan mais recente é Baltimore, the charm city (a cidade do charme).

\section{O "L BRANCO" E A "BORBOLETA NEGRA"}

Brown (2021) observa que o processo de revitalização do espaço urbano de Baltimore aprofundou as desigualdades sociais e raciais do passado. Tal processo reproduziu a lógica já hegemônica na história de Baltimore de concentrar os investimentos nas áreas majoritariamente brancas, enquanto mantém os bairros negros em escassez de bens e serviços públicos e privados. Assim, a segregação racial, que no passado teve respaldo pelo aparato jurídico, ganha uma nova retórica no contexto liberal: tornar a cidade competitiva como destino turístico e para a indústria de eventos e entretenimento (HARVEY, 2015). Brown observa que as transformaçóes políticas, econômicas, socais e demográficas vividas por Baltimore não eliminaram a segregação racial, que é responsável em dividir a cidade em dois desenhos: o "L branco" e "Borboleta negra”.

O "L branco" abarca ao norte, os bairros Mount Washington/Coldspring, Greater Roland Park/Poplar Hill e Gilford/Homeland, passando pelos bairros na região central, como Greater Charles Village, Midtown, Downtown, Inner Harbor e Federal Hill e se estendendo a sudeste pelos bairros Harbor East, Fells Point, Canton e Highlandtown. O "L Branco" historicamente tem recebido investimento de grandes corporaçóes e do governo local em revitalização. Ela concentra escritórios, espaços de lazer, lojas, eventos, restaurantes, arte e cultura, condomínios de moradia para profissionais classe média. Esta é a parte da cidade que faz jus ao título de Baltimore como a "cidade do charme". Essa é a parte da cidade que ocupa as propagandas que tentam aquecer o turismo em Baltimore. A cidade majoritariamente negra embranquece ao ser transformada em produto para consumo turístico (RIZZO, 2019). Como moradora de Baltimore, me tornei uma das privilegiadas que residem no "L branco". 
Figura 4: Porcentagem de residentes negros/afro-americanos, 2012 - 2016

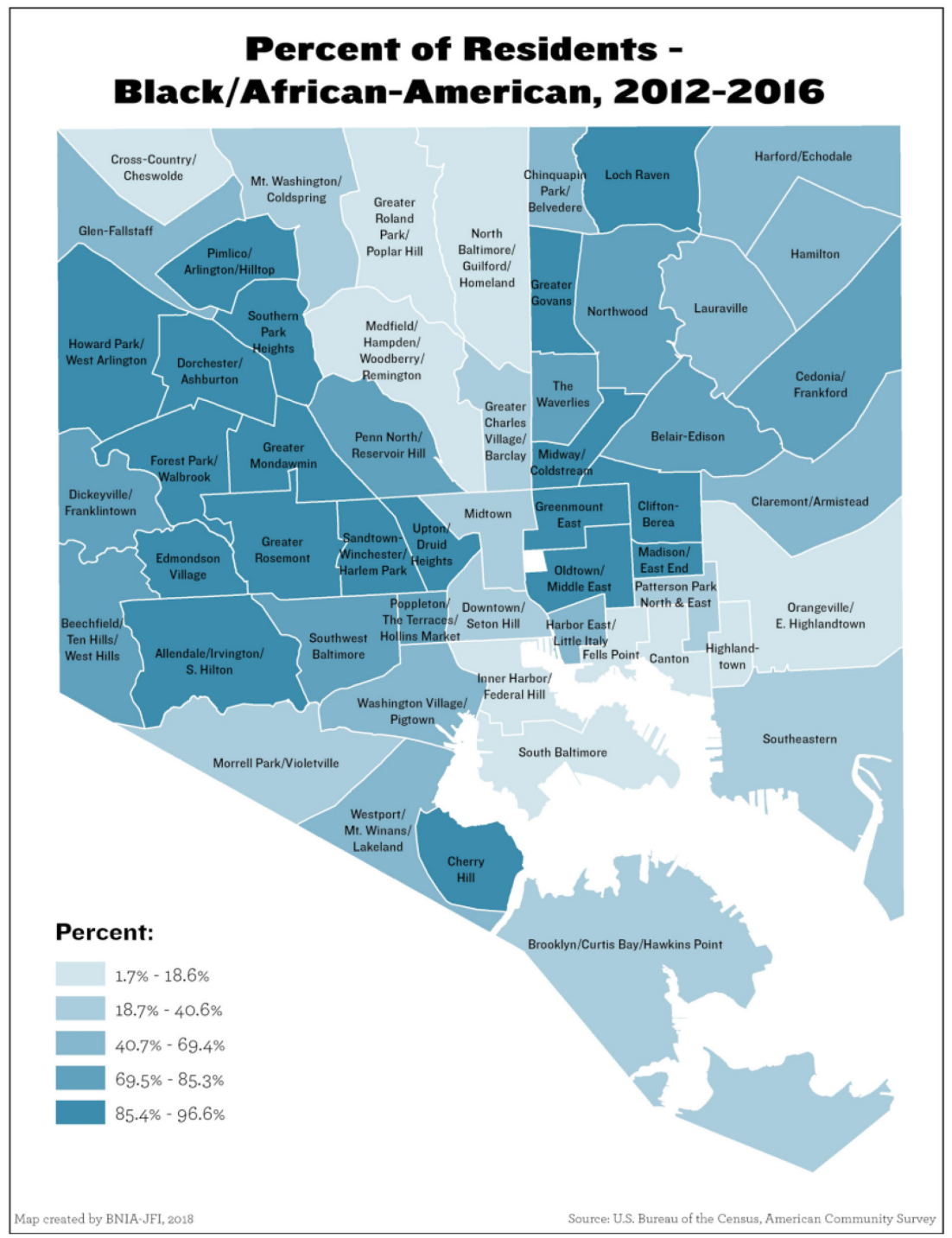

Fonte: American Community Survey - Analysis: Baltimore Neighborhood Indicators Alliance, Jacob France Institute (2018). 


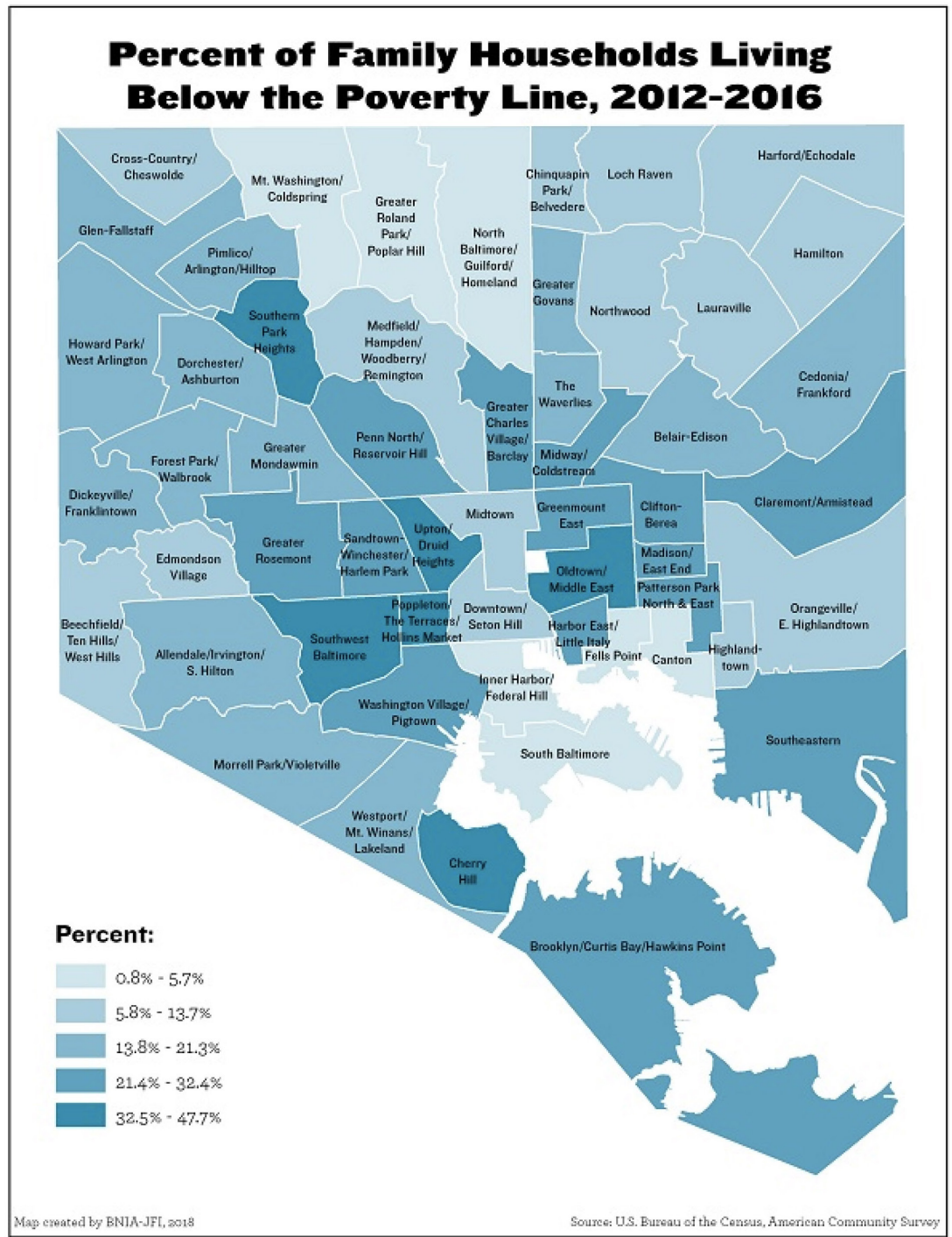

Fonte: American Community Survey - Analysis: Baltimore Neighborhood Indicators Alliance, Jacob France Institute (2018). 
Com o processo de revitalização, as áreas centrais da cidade tem recebido uma geração de novos moradores: pessoas jovens, sem filhos, estudantes e jovens profissionais, principalmente brancos, mas também negros estrangeiros, como eu e a Ifemelu, personagem principal de "Americanah", romance da escritora nigeriana Chimamanda Ngozi Adichie (2014). Na trama, Ifemelu se mudou para Baltimore a convite de seu namorado, um jovem branco da elite, que consegue um emprego para ela. Ifemelu, assim como eu, goza dos privilégios de morar no "L branco" de Baltimore. Curiosamente, foi em Baltimore a primeira vez que, aconselhada pela tia e uma grande amiga também africana, Ifemelu alisou o cabelo. Ambas alertaram Ifemelu que seu cabelo crespo natural poderia espantá-la do trabalho que o namorado tinha conseguido para ela. Foi em Baltimore, cidade predominantemente negra, que Ifemelu "embranqueceu" seu cabelo para conseguir um emprego.

A própria Chimamanda morou em Baltimore quando realizou um mestrado na universidade Johns Hopkins. Além de negras estrangeiras como eu e Chimamanda, o "L branco" abriga também outras raças, etnias e nacionalidades. No prédio onde eu morei, por exemplo, havia um grande número de indianos que se mudaram para Baltimore para estudar e trabalhar na Universidade Johns Hopkins. Eu também conheci vários brasileiros que moravam perto de mim, grande parte deles mulheres brancas pós-graduandas realizando pesquisas também na Johns Hopkins. No meu terceiro mês em Baltimore, fui pela primeira num dos campi da Universidade Johns Hopkins. Finalmente, ia conhecer por dentro a instituição privada que mais emprega na cidade e que tem tido um papel central no processo de transformação do espaço urbano de Baltimore. Quando cheguei no campus da North Charles - a mesma rua onde eu morava - fiquei surpresa.

Ao contrário da Morgan States University, onde eu realizava o pós-doutorado, em que a comunidade docente, discente e de funcionários era quase que exclusivamente negra, a Johns Hopkins era quase que majoritariamente branca. Eu pude contar nos dedos de apenas uma mão o número de pessoas negras que eu vi no campus da universidade. E elas estavam trabalhando como segurança. A Johns Hopkins sem dúvida fazia jus à sua localização no "L Branco". Brown (2016) realizou um levantamento comparando as vantagens estruturais do "L Branco" em comparação com as desvantagens também estruturais da "Borboleta negra”. Entre elas estão:

Sistema de transporte: o "L Branco" tem acesso ao "Charm city circulator", linhas de ônibus grátis financiadas pela prefeitura enquanto a "Borboleta negra” não; 
Rodovias: o "L Branco" foi beneficiado com a construção de rodovias de acesso ao centro da cidade enquanto a "Borboleta negra" tem muitos de seus moradores desalojados para a construção de rodovias;

Politica de investimento urbano: o "L Branco" recebeu centenas de milhôes de dólares em investimentos em revitalização urbana, enquanto a "Borboleta negra", que sofreu no passado com o "redlining", hoje sofre com sua deterioração devido a falta de investimento.

Crédito a pequenos negócios e moradia: $\mathrm{O}$ "L Branco" tem mais acesso a empréstimos a pequenos negócios e ao financiamento de residências, com taxas de juros vantajosas. $\mathrm{Na}$ "Borboleta Negra", o acesso ao crédito, quando acontece, se dá por meio de taxas de juros mais altas. Assim, os pequenos negócios têm dificuldades para conseguir financiamento e os compradores de casa enfrentam o constante risco de não conseguir pagar suas hipotecas e assim, perder suas casas.

Policiamento: no "L Branco", a polícia é cortês; na "Borboleta negra”, ela é violenta e realizam o "Stop-and-frisk" (Parar e revistar: procedimento de parar e revistar moradores, colocando-os em constante suspeita).

Este cenário faz com que Baltimore continue uma cidade racialmente segregada, ao mesmo tempo em que ela se integra aos processos globais de transformaçóes urbanas no capitalismo neoliberal. Como consequência, Baltimore enfrenta profundas desigualdades sociais em interseção com a segregação racial. Analisando o Índice de Desenvolvimento Humano (IDH) dos bairros de Baltimore, 7 dos 10 bairros com o IDH mais baixo têm uma população mais de $90 \%$ negra. Por outro lado, os 10 bairros com IDH mais alto têm mais de $60 \%$ de população branca. O bairro com o IDH mais elevado de Baltimore é Greater Roland Park/Poplar Hill, com a marca de 0.979 , tendo sua população a expectativa de vida de 83.9 e a renda per capita anual de $\$ 73$. 941,63. Upton/Druid Heights é o bairro com o IDH mais baixo de toda a cidade (0.725), tendo sua população a expectativa de vida de 68.2 anos e uma renda per capita anual de U\$13.609,82 (IRANI et al., 2018, p. 5).

Druid Heights acumula uma taxa de desemprego de $17.5 \%$ (enquanto a média municipal é de $11.1 \%$ ); 48,8\% das famílias no bairro vivem abaixo da linha da pobreza, muito acima dos $15,2 \%$ da média da cidade. O bairro apresenta ainda uma taxa de homicídio de $37,9 \%$, comparado aos $20.9 \%$ da média de Baltimore (AMES et al., 2011; BROWN, 2015). Apesar das estatísticas negativas da atualidade, Druid Heights tem uma grande importância para a 
história negra de Baltimore e dos Estados Unidos, como mostra o mural da Figura 6. No entanto, essa história está ameaçada de cair no esquecimento. As precárias condiçóes de vida e infra-estrutura e a violência mantém a segregação no bairro ainda hoje. Assim, a área não é incluída na rota de turismo, lazer, esporte e negócios que caracteriza o redesenvolvimento de Baltimore no contexto neoliberal.

Figura 6: Mural em homenagem aos expoentes afro-americanos John H. Murphy, Harry S. Cummings, Lawrence Mitchell, Thurgood Marshall, Lillie Jackson.e Teachlew W. Lansey na Avenida Druid Hill, no bairro Druid Heights/Upton. No entorno, imóveis deteriorados.

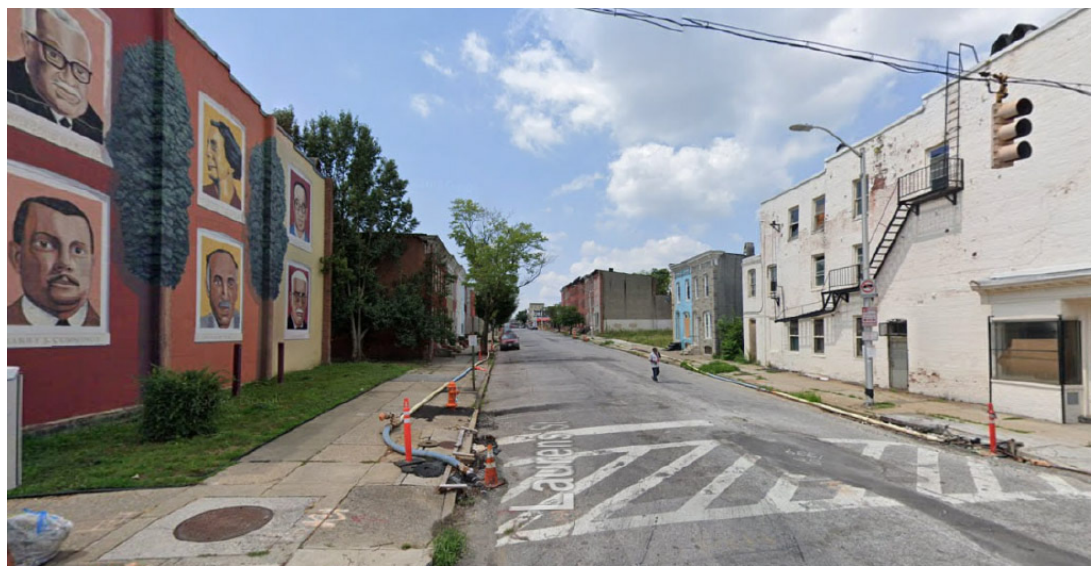

Fonte: Street View, Google Maps. Acesso em 22 Fev. 2021.

\section{RAÇA, CLASSE E FLUXOS MIGRATÓRIOS EM BALTIMORE}

Em Baltimore, a imigração também exerce um importante papel na exacerbação da tensão racial e do agravamento das desigualdades. O crescimento econômico no início do século XX atraiu imigrantes brancos de países como Alemanha, Polônia, Lituânia e Itália. A cidade também acolheu a migração interna de negros e brancos do sul do país. Como recém-chegados, os imigrantes europeus encontraram resistência de muitos setores. Os imaginários xenófobos os consideravam uma possível ameaça aos "bons hábitos" e à identidade nacional. No entanto, eles foram priorizados como força de trabalho para ocupar cargos e funçóes mais prestigiadas e bem remuneradas que aquelas deixadas para os trabalhadores negros. Quando finalmente contratados, os negros eram impedidos de acessar os cargos mais bem pagos. Apesar das eventuais tensôes étnicas entre americanos brancos e imigrantes brancos, 
eles tendiam a unir forças contra a mobilidade ascendente dos trabalhadores negros e à favor da segregação racial (DURR, 2003).

Os imigrantes brancos também se beneficiaram do racismo na política urbana. Tanto as comunidades negras como as imigrantes sofreram com a falta de moradia. No entanto, o investimento em moradia para imigrantes brancos foi mais bem aceito pela sociedade local do que para negros (McDOUGALL, 1993, p. 39). Por exemplo, na década de 1940, o governo elaborou um plano para construir casas públicas no sudeste de Baltimore região que hoje localiza-se no "L Branco". A primeira parte do plano visava construir um conjunto habitacional - um project - para imigrantes. O plano recebeu reaçóes negativas dos moradores locais, que disseram que os imigrantes prejudicariam sua vizinhança. Mesmo assim, eles acabaram tolerando o plano, finalmente construído em 1943. A segunda parte construiria um conjunto habitacional para famílias negras. O plano foi rejeitado pelos moradores locais e transferido para Cherry Hill, sudoeste da cidade (DURR, 2003, p. 24-25), na asa inferior esquerda da "Borboleta negra" (ver Figuras 4 e 5). Enquanto reproduzindo estereótipos contra imigrantes brancos, os vizinhos brancos estavam mais propensos a aceitá-los em seu bairro. Assim, a raça pesava mais nessa conta do que a nacionalidade. Hoje, Cherry é o segundo bairro com a maior população negra de Baltimore (95,7\%) e o segundo mais pobre, com 45,1\% das famílias vivendo na pobreza (BROWN, 2015).

O planejamento urbano em Baltimore tem sido um mecanismo oficial de segregação desde 1900. Os negros - independentemente da classe - foram empurrados para determinadas partes da cidade, como o oeste, ao mesmo tempo que impedidos de residir nos bairros brancos. Os imigrantes brancos se instalaram majoritariamente no sul e no leste da cidade. Highlandtown, o bairro no sudeste da cidade onde a comunidade latina está hoje concentrada, costumava abrigar uma comunidade alemã (MCDOUGALL, 1993, p. 47).

Reagindo ao movimento pelos direitos civis, nos anos 70 muitas famílias da classe trabalhadora branca começaram a reivindicar suas origens étnicas como descendentes de imigrantes europeus, resistindo à narrativa de assimilação - e o imaginário dos Estados Unidos como um "melting pot" - das décadas anteriores. O governo federal pressionou contra a segregação racial apesar dos esforços do município em mantê-la, porém a dessegregação foi contestada por vários setores brancos de Baltimore. A reivindicação de uma branquitude étnica, ou seja, com uma história, língua e cultura diferentes da cultura nacional, contribuiu para a formação dos movimentos de bairros para protegê-los contra às pressões do mercado imobiliário e à entrada de moradores negros (DURR, 2003, p. 102). 
Evitando o vocabulário racista da era Jim Crow, os brancos adaptaram sua narrativa às novas demandas dos direitos civis dos EUA. A classe trabalhadora branca do sudeste de Baltimore, especialmente as mulheres brancas, protestou contra a dessegregação escolar, por exemplo. Elas não queriam que seus filhos fossem para escolas negras. No entanto, elas se diziam abertas para receber jovens negros em suas escolas brancas. Elas alegavam que apoiavam a dessegregação desde que seus filhos não fossem obrigados a se deslocar para bairros negros para estudar. Para Durr, isso indicava que a classe trabalhadora branca não estava alinhada com o racismo, mas sim com um forte senso de comunidade e apego à vizinhança que se aprofundou com as políticas identitárias pós-movimento pelos direitos civis (DURR, 2003, p. 166-171).

No entanto, a ausência de um vocabulário abertamente racista pode não necessariamente indicar o fim do racismo, mas sim que o racismo está disfarçado por uma narrativa de cegueira racial, naquela época nova em Baltimore, mas dominante na América Latina, de onde eu me origino. A suposta cegueira racial nos Estados Unidos pós-movimento de direitos civis tem gerando o que Bonilla-Silva (2003) chama de "racismo sem racistas": as desigualdades sistêmicas do racismo são reproduzidas mesmo na integração, que celebra as relações interraciais, mas não cria mecanismos que corrijam as desigualdades do racismo estrutural. Assim, o racismo como sistema de opressão que beneficia pessoas brancas permanece intocado.

A luta contra o racismo estrutural em Baltimore não é recente. A cidade desempenhou um papel importante no ativismo negro histórico, como o movimento abolicionista, a guerra civil e os movimentos pelos direitos civis. Baltimore fomentou um movimento negro vivo e contínuo, como sede da Associação Nacional para o Avanço das Pessoas de Cor (NAACP) e uma das filiais do antigo partido Pantera Negra (MCDOUGALL, 1993). Baltimore também hospeda a Morgan State University, pertencente à liga de faculdade e universidades historicamente negras (Historically Black Colleges and Universities - HBCU) fundada para receber jovens negros rejeitados pelas universidades brancas. $\mathrm{O}$ movimento anti-racista em Baltimore continua vívido. Em 2015, Baltimore se tornou parte do movimento \#Blacklivesmatter, quando Freddie Gray, um jovem negro do oeste de Baltimore, foi morto sob custódia policial. As manifestaçóes após os assassinatos de Freddie Gray em 2015 e George Floyd em 2020 indicam que muitos moradores de Baltimore são críticos ao racismo.

A maioria dos imigrantes não entende o racismo estrutural que historicamente alimenta a segregação racial de Baltimore. Grande parte deles também é influenciada pela anti-negritude dominante na mídia de massa e no senso comum. População mais afetada pelo desinvestimento, por políticas - públi- 
cas e privadas - discriminatórias e pela pobreza, os negros ainda enfrentam estereótipos que os descrevem como preguiçosos, violentos e criminosos (CASIANO, 2019). Estes estereótipos os desumanizam, ignorando suas realizações, apesar das opressões interseccionais. Várias instituições onde imigrantes altamente qualificados - mesmo os não-brancos - trabalham são dominadas pela classe média branca. Ambos tendem a se alinhar ao pretenso daltonismo da "era pós-racial", enquanto o racismo abunda fora de seus escritórios e laboratórios. Assim, eles ignoram o papel de suas instituiçôes e deles mesmos - no agravamento das desigualdades em Baltimore.

Do lado de fora do hospital Johns Hopkins, no sudeste de Baltimore, por exemplo, uma população majoritariamente negra duramente empobrecida lutou para resistir à tomada de seu bairro pelos empreendimentos da instituição (GOMEZ, 2019; 2013). Além do hospital, a Johns Hopkins possui empreendimentos em muitas outras áreas da cidade. Junto com seus prédios, estudantes, pesquisadores e funcionários contribuem para empurrar para fora do seu entorno as populações negras que ali moram para dar passagem ao "desenvolvimento".

Em conversa com uma brasileira branca que trabalhava como pesquisadora na Johns Hopkins, ela reclamou que se sentia discriminada pelos negros de Baltimore, sentimento que nunca teve no Brasil. Declarando não ser racista, já que tem muitos amigos negros no Brasil, ela concluiu que Baltimore era muito mais racista do que sua cidade natal, o Rio de Janeiro, também minha cidade natal. Eu disse a ela que os negros de Baltimore tinham muitas razóes para evitar a presença de pessoas brancas. Dei como exemplo o fato da Johns Hopkins, a instituição onde ela trabalhava, estar localizada numa cidade majoritariamente negra, mas você não vê negros trabalhando em empregos altamente qualificados ou estudando lá. Ela concordou comigo. Ela contou que os poucos negros que trabalhavam com ela eram imigrantes, principalmente de países africanos. Os únicos negros americanos que ela via no campus eram os seguranças. O que ela provavelmente não sabe é que, além de ser uma instituição majoritariamente branca numa cidade negra, a Johns Hopkins tem desempenhado um papel central na gentrificação de Baltimore, de norte a sul. A instituição também tem contribuído para a proliferação de empregos precários, já que, nos anos 80 , inaugurou uma subsidiária de serviços de limpeza e segurança terceirizados para atender a própria Johns Hopkins e outras empresas (HARVEY, 2015). Assim, a população negra e pobre tem na raiva uma forma de expressar sua indignação contra os processos globais de desigualdades que agravam a segregação racial em Baltimore ainda hoje. 


\section{ALÉM DO PRETO E BRANCO: OS LATINOS EM BALTIMORE}

Enquanto na virada para o século XXI a população de Baltimore diminuía, a população latina cresceu significativamente, passando de 7.602 pessoas em 1990 para 17.014 em 2008, de acordo com os dados oficiais. No entanto, organizações latinas em Baltimore estimaram que entre 25.000 e 35.000 latinos viviam em Baltimore em 2011. A população latina de Baltimore inclui imigrantes e americanos de ascendência latino-americana, residindo principalmente no sudeste de Baltimore, nos bairros Fells Point, Patterson Park, Highlandtown e Canton. Em 2007, os latinos formaram o segundo grupo mais pobre de Baltimore, com $17 \%$ da população afetada pela pobreza, comparada a $24 \%$ dos negros; $13 \%$ dos asiáticos e $15 \%$ dos brancos. Nacionalmente, 22\% dos latinos viviam em condiçóes de pobreza (BALTIMORE CITY HEALTH DEPARTMENT, 2011).

A inserção dos Latinos no espaço urbano de Baltimore revela questóes cruciais em relação ao racismo tanto da "linha de cor" quanto da "cegueira racial". No caso do racismo da "linha de cor", acredita-se que negros e brancos são diferentes, separados por uma linha, demarcada pela regra de uma gota de sangue: uma gota de sangue negro tornaria você negro. Tal ideologia fundamentou as políticas de segregação racial em Baltimore. Muito similar à linha que divide humanos e "não-humanos" (FANON, 2008), a "linha de cor" no espaço urbano impedia os negros de cruzar a linha divisória para as partes mais desenvolvidas, que eram áreas brancas. Em contrapartida, a "cegueira racial” explica que a sociedade não teria na raça um critério importante na sua sociabilidade, prevalecendo a mistura. Ela dialoga com a ideologia da mestiçagem hegemônica na América Latina. Ambas escamoteiam que a mistura não acaba com as desigualdades.

Em Baltimore, os latinos convivem cotidianamente com as duas ideologias. A materialização da "linha cor" no espaço urbano tem como consequência a hiper-segregação de negros e brancos que deixa os latinos num lugar dúbio, pois não integram nenhum dos dois extremos da linha. É importante ressaltar que os latinos são um grupo étnico que sofre um processo de racialização nos Estados Unidos. A racialização seria o processo através do qual determinados sujeitos são considerados menos humanos - e por isso discriminados - de acordo com características como o fenótipo, a origem nacional, a religião, as identidades étnicas e o status migratório (FALQUET, 2008). Grosfoguel e Maldonado (2008) observam que o Estado nacional ocupa um importante papel em racializar negativamente determinados grupos, os "sujeitos coloniais". Excluídos da nação como "comunidade imaginada" imaginada como branca -, os sujeitos coloniais não são reconhecidos como portadores de direito e têm sua exploração como força de trabalho legiti- 
mada por estereótipos raciais, tornando-se cidadãos de segunda classe em seu próprio país, como acontece com os afro-estadunidenses.

Similar à experiência dos "sujeitos coloniais" é a dos "imigrantes coloniais”. Eles são indivíduos não-brancos oriundos de países periféricos que se inserem no mercado de trabalho como mão de obra mal-remunerada, sem acesso a direitos. A imigração deles é distinta da dos "imigrantes", brancos europeus que, apesar das diferenças étnicas, foram assimilados à identidade estadunidense, como aconteceu com alemães, poloneses, italianos, etc em Baltimore. A racialização dos latinos/hispânicos (ALCOFF, 2000; MENDIETA, 2000; OBOLER; 2010) demonstra que a raça nos Estados Unidos se metamorfoseou, pressionando a sociedade estadunidense a repensar o binarismo negro-branco.

Enquanto os latinos brancos podem eventualmente ser confundidos como americanos brancos, desfrutando dos privilégios da branquitude, os latinos com fenótipo negro ou indígena não têm essa chance. Eles carregam no corpo a marca da dominação colonial (SEGATO, 2010). No caso deles, a identidade étnica como latinos e o fenótipo não-branco se interseccionam, agravando a sua racialização. Os latinos com fenótipo não-branco também enfrentam a discriminação racial dentro da própria comunidade. Em muitos casos, os latinos brancos ou mestiços claros de classe média se destacam, assumindo o papel de "representantes" de todos os latinos em Baltimore. Ainda que não intencionalmente, muitos deles terminam silenciando as vozes latinas não-brancas e mais vulneráveis.

Em 2007, 19\% dos latinos em Baltimore eram negros (BALTIMORE CITY HEALTH DEPARTMENT, 2011). Os latinos negros encontram uma experiência única, pois vários deles são confundidos como negros americanos. Assim, eles podem circular por espaços negros hostis à presença de não-negros. Entretanto, também estão sujeitos ao racismo anti-negro tanto da sociedade estadunidense, quanto na comunidade latina. No caso da comunidade negra estadunidense, parte da dificuldade em aceitá-los está vinculada às diferenças étnicas e nacionais. Por exemplo, no meu caso, como negra e brasileira, eu era vista como negra, mas era rejeitada assim que os negros estadunidenses de Baltimore ouviam meu sotaque. Por outro lado, muitos latinos negros também são discriminados por outros latinos, que pensam que elas são negros estadunidenses. Os latinos negros estão localizados no meio do fogo cruzado. Por exemplo, até conseguir construir uma rede de sociabilidade por meio da militância anti-racista, eu não era aceita nem pelos negros estadunidenses, nem pelos latinos não-negros (DANIEL, 2019). Ainda assim, minha condição de classe como professora universitária me dava acesso a privilégios como morar no "L branco". Usufruindo dos pri- 
vilégios e das desvantagens de ser negra, latina, brasileira e intelectual, sempre que possível contribuo para combater a anti-negritude na comunidade latina em Baltimore, com a qual mantenho profundos laços, e a xenofobia antilatina entre negros estadunidenses.

A relação entre negros americanos e latinos, em sua maioria não-negros, é mediada por estereótipos mútuos de anti-negritude - negros como criminosos - e de xenofobia - latinos como ladrões de empregos. Isso gera entre eles uma tensão racial que é explorada, por exemplo, pelos empregadores. Vários deles preferem a força de trabalho latina, representada como mais dedicada e subserviente para o setor de serviço, principalmente de limpeza. Além disso, muitos deles contratam imigrantes latinos, especialmente os indocumentados, com salários mais baixos. Como resultado, a animosidade entre negros e latinos se aprofunda, às vezes se manifestando em violência. Uma estratégia de proteção que os latinos em Baltimore têm desenvolvido é restringir sua circulação aos espaços da cidade que concentra a população latina.

A hostilidade entre negros e latinos abastece o racismo no nível micro. Ela também manifesta outras camadas do racismo estrutural e sua combinação com o capitalismo global. Apesar da sua próspera classe média negra, incluindo professores, artistas e políticos, Baltimore é fortemente afetada pelo neoliberalismo que mantém a cidade nas primeiras posições no ranking das cidades mais pobres e violentas dos EUA e os negros como a população mais afetada. As corporaçóes pressionam a política institucional para priorizar os lucros em vez dos interesses coletivos. Os imigrantes latinos são cruciais nesse processo, integrados ao mercado de trabalho local em condiçóes mais vulneráveis do que a força de trabalho americana, principalmente no setor de serviço. Dentro dele, a área de limpeza é um nicho onde predomina a presença latina. Além de ter recebido uma migração histórica no início do século XX como força de trabalho para as emergentes indústrias, Baltimore tem no século XXI a imigração como parte de sua política de desenvolvimento. Com políticas de imigração muito mais democráticas que outras partes dos Estados Unidos, Baltimore espera atrair mais imigrantes que contribuam para reverter a queda populacional sofrida nas últimas décadas do século XX.

No entanto, muitos latinos se ressentem do orgulho racial dos negros e da raiva que eles demonstram sobre a pobreza, acreditando que os negros reclamam muito e trabalham pouco. Enquanto muitas vezes reforçam o racismo anti-negro, muitos trabalhadores latinos precisam lidar com condiçôes precárias de vida. A vulnerabilidade da comunidade latina em Baltimore se tornou mais visível durante a pandemia. Representando $5 \%$ da população local, os latinos somam $15 \%$ dos infectados pela Covid-19 ${ }^{1}$. Diferente- 
mente dos imigrantes europeus do início do século 20 que aproveitaram o privilégio branco para serem assimilados pela identidade nacional estadunidense, os latinos se encontram entre a racialização e o desejo de assimilação. Muitos latinos, esperançosos de algum dia serem aceitos jurídica e simbolicamente como cidadãos, compactuam com a branquitude e se somam às narrativas anti-negras. Preocupado com tal realidade, o Mayor's Office of Immigrant Affairs (MIMA) tem incluído o letramento racial como parte de sua política ${ }^{2}$. Também há iniciativas na comunidade latina para combater a segregação racial e a discriminação, como fazia o coletivo de arte-ativismo Neighborhood Voices, do qual fui parte, e no campo educacional faz o SOMOS - Students Organizing a Multicultural and Open Society.

\section{CONSIDERAÇÕES FINAIS}

As tensões do seu espaço urbano materializam as desigualdades do mundo capitalista e sua interseção com a raça, a imigração e outros sistemas de opressão. Seja nos períodos de crescimento econômico ou nos períodos de crise; nos períodos de crescimento populacional ou nos períodos de queda; seja quando era proibida de votar e ser votada ou quando hoje ocupa a chefia do executivo e 10 dos 15 assentos do legislativo, a população negra de Baltimore continua a maioria entre os pobres e os bairros negros os que recebem menos investimentos, ficando mais distantes do que faz Baltimore a "cidade do chame".

Na história de Baltimore, a imigração tem um papel muito importante nas desigualdades de raça e classe. No início do século, as ofertas de emprego no setor industrial atraíram um grande número de imigrantes europeus brancos. Apesar da xenofobia no encontro com os brancos estadunidenses, os imigrantes brancos usufruíram das oportunidades de trabalho, moradia e educação racialmente segregadas. Assim, eles foram incorporados à identidade nacional estadunidense protegidos pelo privilégio branco. Este processo em muito se assemelhava ao processo de imigração europeia no mesmo período no Brasil. Apesar das dificuldades enfrentadas pelos imigrantes brancos recém-chegados, eles foram material e simbolicamente aceitos como parte da nação, cujo objetivo era o branqueamento (SEYFERTH, 1996). Em contrapartida, as populações negras foram empurradas para o papel de “sujeitos coloniais" (GROSFOGUEL e MALDONADO-TORRES, 2008) no pós-abolição. Ambos os casos apontam para o pacto do projeto nacional com o privilégio branco e a manutenção do racismo estrutural que legitima as desigualdades. 
Em Baltimore hoje, a imigração continua tendo um papel central. A prefeitura tem a esperança que a imigração contribua para a recuperação da cidade, fornecendo força de trabalho - principalmente na prestação de serviços, como o de limpeza - e pagando impostos. Por isso, ela tem adotado políticas migratórias progressivas, inclusive tentando resistir ao recrudescimento da política de imigração federal. Um exemplo é que Maryland, estado que abriga Baltimore, é um dos poucos estados que permite que os imigrantes indocumentados tirem a carteira de motorista. Atraídos pela política de imigração, as oportunidades de emprego e a oferta de moradia mais barata que outras cidades da costa leste, muitos latinos decidem morar em Baltimore. Ao contrário dos imigrantes brancos do início do século $\mathrm{XX}$, os imigrantes latinos encontram muito mais dificuldades para serem aceitos como parte da identidade nacional estadunidense, sofrendo com a racialização. Ainda assim, o percentual mais baixo de pobreza dos latinos em relação aos negros e seu estabelecimento no sudeste da cidade, área historicamente branca pode indicar que os latinos têm a chance de se beneficiarem da anti-negritude (VARGAS, 2016) que aprisiona a população e os bairros negros na pobreza. Estes indícios podem apontar que, num futuro próximo, os latinos tenham mais chances de serem incorporados ao projeto estadunidense de cidadania que os negros.

Como brasileira negra de classe média, eu me inseria em outras tensões que evidenciam a desigualdade na dimensão simbólica e intersubjetiva. De um lado, eu encontrava pessoas brancas em Baltimore abertas para se relacionar comigo. Muitas vezes esse acolhimento escondia o desejo delas - consciente ou não - de experimentar uma relação interracial. Isto significaria que elas se sentiriam não-racistas sem tem quer lidar com as tensões da relação com os afro-estadunidenses que, consistentes da história da cidade, demandam dos brancos um posicionamento frente à segregação racial e o racismo estrutural. Pelos afro-estadunidenses, eu às vezes era tratada com familiaridade. Ela se dissipava quando eles percebiam que eu era negra, mas não estadunidense. Nas poucas vezes que interagi com afro-estadunidenses numa posição de classe similar à minha, em algumas delas fui silenciada ou desacreditada, o que demonstrava seu sentimento de superioridade frente a uma mulher negra brasileira. Por outro lado, minha relação com os latinos é quase sempre permeada pela hostilidade que muitos deles demonstram contra os afro-estadunidense até descobrirem que sou brasileira. Foi na comunidade latina que eu me inseri. Esta inserção aconteceu através do meu engajamento no ativismo anti-racista liderado por latinos.

Do meu lugar como mulher, negra, latina, brasileira e intelectual em Baltimore, pude navegar por diferentes camadas de opressóes que caracteri- 
zam a complexa vida na cidade. Algumas dessas opressôes eu vivi de forma interseccional. Porém, minha posição de classe também me deu recursos para me proteger de outras, como morar na parte da cidade com mais infra-estrutura, proteção que muitos negros nascidos e criados em Baltimore ou imigrantes latinos indocumentados não têm. A despeito das pressões neoliberais, Baltimore resiste. Uma complexa gama de movimentos sociais, organizações de base e instituições religiosas elaboram narrativas e políticas contra-hegemônicas sobre a cidade, contra a pobreza e a violência. Ancoradas na histórica resistência que Baltimore teceu, estas iniciativas costuram os fios do sentimento de pertencimento que tornou os Baltimoreans e ex-visitantes, como eu, orgulhosos da cidade. Deste orgulho pode surgir projetos alternativos de desenvolvimento interraciais anti-racistas que não se rendam nem ao branqueamento nem à cegueira racial da "cidade do charme e que combata a anti-negritude que explora a imigração para agravar as desigualdades raciais.

\begin{abstract}
Notas
'https://mayor.baltimorecity.gov/news/press-releases/2020-12-18-mayor-brandon-m-scott-announces-initiative-mitigate-disproportionate. Acesso em: 10 may. 2021.

2 Em 2019, MIMA incluiu em seu programa de formação de líderes da comunidade imigrante, o "new Americans task force", uma sessão sobre racismo e segregação racial em Baltimore. Eu assisti a sessão, a convite da coordenadora do programa.
\end{abstract}

\title{
Referências
}

ADICHIE, C. N. Americanah. São Paulo: Cia das Letras, 2014.

ALCOFF, L. Is Latino/a a racial identity?. In: GARCIA, J.; DE GRIEFF, P. (eds.). Hispanics/ Latinos in the United States: ethnicity, race, and rights. Abingdon: Routledge, 2000, pp. 23-44.

BILGE, S., COLLINS, P. Intersectionality. Cambridge: Polity, 2016.

BONILLA-SILVA, E. Racism without racists: color-blind racism and the persistence of racial inequality in the United States. Lanham: Rowman and Littlefield, 2003.

BROWN, L. The Black Butterfly: the harmful politics of race and space in America. Baltimore: Johns Hopkins University Press, 2021.
CASIANO, M. "the Pot": criminalizing Black neighborhoods in Jim Crow Baltimore. In: KING, N.; DRABINSKI, K., DAVIS, J. C. (orgs.). Baltimore revisited: stories of inequality and resistance in a U.S city. New Brunswick, New Jersey: Rutgers University Press, 2019. pp. 37-51.

COLLINS, P. Pensamento feminista negro: conhecimento, consciência e política. São Paulo: Boimtempo, 2019.

COLLINS, P. Aprendendo com a outsider within: a significação sociológica do pensamento feminista negro. Sociedade e Estado, v. 31, n. 1, pp. 99-127, 2016. Acesso em: 10 jul. 2020.

COMBAHEE RIVER COLLECTIVE. A Black feminism statement. In: MORAGA, C.; ANZALDÚA, G. (orgs.). This bridge called my back: writings by Radical Women of Color. Albany: State University of New York, 2015. 
DANIEL, C. "Morena": a epistemologia feminista negra contra o racismo no trabalho de campo. Humanidades e Inovação, v. 16, n. 6, pp. 23-34, 2019. Acesso em: 15 dez. 2019.

DANIEL, C. Os sentidos da raça na experiência transnacional de peruanos no Brasil e nos Estados Unidos. In: ELMIR, C. P.; TRUZZI, O.; WITT, M. A. (orgs.). Imigração nas Américas: estudos de história comparada. Porto Alegre: OIKOS, 2018, pp. 20-43.

DIAS, L. De O. Quase da família: corpos e campos marcados pelo racismo e pelo machismo. Humanidades e Inovação, v. 6, n. 16, pp. 1-7, 2019.

DURR, K. D. Behind the blacklist: white working-class politics in Baltimore, 1940-1980. Chapel Hill: University of North Carolina Press, 2003.

FALQUET, J. Repensar as relações sociais de sexo, classe e "raça" na globalização neoliberal. Mediações, v. 13, n. 1/2, pp. 121-142, 2008.

FANON, F. Pele negra, máscaras brancas. Salvador: EdUFBA, 2008.

FRASER, N. Da redistribuição ao reconhecimento? Dilemas da justiça na era "póssocialista". Cadernos de Campo, n. 14/15, p. 1-382, 2006.

GOMEZ, M. B. Johns Hopkins University and the history of developing East Baltimore. In: KING, N.; DRABINSKI, K., DAVIS, J. C. (orgs.). Baltimore revisited: stories of inequality and resistance in a U.S city. New Brunswick, New Jersey: Rutgers University Press, 2019. p. 243- 256.

GOMEZ, M. B. Race, class, power, and organizing in East Baltimore: rebuilding abandoned communities in the America. Lanham: Lexington books, 2013.

GONZALEZ, L. A categoria político-cultural de amefricanidade. Tempo Brasileiro, v. 92/93, n. 1, pp. 69-82, 1988.
GROSFOGUEL, R. \& MALDONADO-TORRES, N. Los latinos, los migrantes y la descolonización del imperio estadounidense en el siglo XXI. Tabula Rasa, n. 9, v. 1, pp. 117-130, 2008.

HARVEY, D. Espaços de esperança. 7. ed. São Paulo: Edições Loyola, 2015.

IRANI, D; SIERS, M.; RICE, M.; BAST, E. Human Development Index disparities in Baltimore City. Regional Economic Studies Institute, 2018. Disponível em https://bit.ly/ 3feUdUZ. Acesso em 28 jan. 2021.

MENDIETA, E. The making of new people Hispanizing race. In: GARCIA, J.; DE GRIEFF, P. (Ed.). Hispanics/Latinos in the United States: ethnicity, race, and rights. Psychology Press, Routledge, Abingdon: 2000, pp. 45-60.

MORAGA, C. \& ANZALDÚA, G. Introduction. In: MORAGA, C.; ANZALDÚA, G. (orgs.). This bridge called my back: writings by Radical Women of Color. Albany: State University of New York, 2015.

OBOLER, S. Nativismo, imigração e pertencimento: latinos nas (ir)realidades americanas do século XXI. Desigualdade \& diversidade, n. 7, pp. 35-62, 2010.

OMI, M. \& WINANT, H. Racial formation in the United States: from the 1960s to the 1990s. 2. Ed. New York: Routledge, 1994.

PIRES, T. Direitos humanos e Améfrica Ladina: Por uma crítica amefricana ao colonialismo jurídico. LASA Forum, v. 50, n. 3, pp. 69 - 76, 2019. Acesso em 24 jan. 2021. Disponível em: https://bit.ly/3vhRmAd.

POWER, G. Apartheid Baltimore style: the residential segregation ordinances of 19101913. Maryland Law Review, v. 42, n. 2, p. 289328, 1983. Disponível em: https://bit.ly/3ugqpvM. Acesso em: 25 jan. 2021. 
QUIJANO, A. 2000. Colonialidad del poder, eurocentrismo y América Latina. In: LANDER, E. (comp.). La colonialidad del saber: eurocentrismo y ciencias sociales. Buenos Aires: CLACSO, 2000. pp. 201-246. Disponível em: https://bit.ly/2SoCxxe. Acesso em: 20 dez. 2019.

RIZZO, M. Image and infrastructure: making Baltimore a tourist city. In: KING, N.; DRABINSKI, K., DAVIS, J. C. (orgs.). Baltimore revisited: stories of inequality and resistance in a U.S city. New Brunswick, New
Jersey: Rutgers University Press, 2019. pp. 243- 256.

SEYFERTH, G. Construindo a nação: hierarquias raciais e o papel do racismo na política de imigração e colonização. In: MAIO, M. C \& SANTOS, R. V. (org). Raça, ciência e sociedade. Rio de Janeiro: Fiocruz, 1996, pp.41-58.

TELLES, E. O significado da raça na sociedade brasileira. Versão para a internet, [2004] 2012.

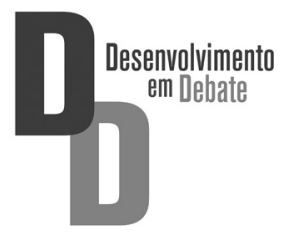

